\title{
The role of temperature and the NAO index in the changing snow- related variables in European regions in the period 1900-2010
}

\author{
AnNA KIS ${ }^{1}$ and Rita PONGRÁCZ ${ }^{1}$
}

\begin{abstract}
Snow-related variables are analysed in the present paper in the period 1901-2010 on the basis of the ERA-20C dataset. Relationships between different snow characteristics, temperature and the NAO index are investigated on monthly, yearly and decadal scales for eight regions within Europe representing different climatic types (i.e. oceanic, continental, polar) to analyse the differences and similarities between them depending on the climatic conditions. According to our results, the ratio of snow (i.e. snowfall compared to total precipitation) can reach 1 in winter in the colder, northern regions, whereas it is about 0.6 in the continental areas of Central Europe, even in the coldest months. During a strong positive phase of NAO more snow falls in the northern regions of Europe due to the large-scale circulation characteristics. When a negative NAO phase occurs, the temperature and snowfall anomalies are the opposite in northern Europe. The highest temperature values generally occurred after 2000, and the snowfall amount was smaller in the first decades of the $21^{\text {st }}$ century compared to the previous decades. The relationship between temperature and snowfall is the strongest in autumn in the colder regions; in spring in the continental areas and in winter in the oceanic climate.
\end{abstract}

Keywords: snowfall ratio, ERA-20C, winter climate, decadal change, regional warming, North Atlantic Oscillation

Received September 2021, accepted November 2021.

\section{Introduction}

Snow cover has impacts in the Earth System, as it plays an important role in surface energy fluxes (e.g. Ellis, A.W. and Leathers, D.J. 1998) via its high albedo, in atmospheric circulation (e.g. Cohen, J. and Rind, D. 1991) and in catchment hydrology (e.g. RotTLeR, E. et al. 2020) via delaying precipitation towards runoff. Furthermore, snow determines soil moisture (Petersky, R. and Harpold, A. 2018), soil water saturation in the first part of the growing season (Ротороvá, V. et al. 2016), еvaporation (Milly, P.C.D. and DunNe, K.A. 2020), and freshwater availability (FonTrodonA $\mathrm{BACH}$, A. et al. 2018). It can also moderate soil temperature, hence snow acts as a ground in- sulator with the capability of protecting plants from frost damage (OKE, T.R. 1987). Therefore, it is important to analyse the past tendencies of snow-related variables, so we can possibly deal with the simulated future changes and make adaptation strategies in time.

The Special Report on the Ocean and Cryosphere in a Changing Climate (IPCC 2019) claims that a general decline in low-elevation snow cover emerged in the recent decades according to the observations. The snow extent of the northern hemisphere had a maximum in the period 1950-1970; since 1980 a reduction can be seen. Snow mass also shows a negative trend based on the ensemble of six observation-based dataset (MUDRYK, L. et al. 2020). According to the Global Historical

\footnotetext{
${ }^{1}$ ELTE, Eötvös Loránd University, Institute of Geography and Earth Sciences, Department of Meteorology, Pázmány P. sétány 1/A, 1117 Budapest, Hungary. E-mails: kisanna@nimbus.elte.hu, prita@nimbus.elte.hu
} 
Climatology Network Daily dataset (Menne, M.J. et al. 2012), maximum snow depth decreased in many European stations during the period 1960-2015. This process is clearly caused by the poleward and upward elevation shift of snow due to higher temperature values (Kunkel, K.E. et al. 2016). FontrodonA BACH, A. et al. (2018) found that mean snow depth decreased more than extreme snow depth in Europe from 1951, and these trends accelerated after the 1980s. KunKeL, K.E. et al. (2016) found that snowmelt starts earlier in spring, especially at higher latitudes due to the Arctic amplification (ZHANG, J. 2005; Hernández-Henríquez, M.A. et al. 2015).

In Europe, continental snow conditions may be associated with certain large-scale processes and/or pressure patterns. For instance, KIM, Y. et al. (2013) showed that the North Atlantic Oscillation (NAO) is related to European snow cover, especially in January and February: a negative NAO phase (i.e. when the meridional pressure gradient over the North Atlantic region is weaker than usual) results in a snow cover increase, while temperature is lower on average.

In those areas where a relatively large amount of snow accumulated during winter, as the weather gets warmer, it starts to melt and becomes part of the runoff, thus, snowmelt-induced floods can occur in spring. Floods can cause serious damages to the economy and they may also demand human lives; the flood-related losses have increased in recent years (Kundewicz, Z.W. et al. 2014). Hydropower can also be affected, as river runoff conditions may change because of altered snowfall, snow cover and snowmelt characteristics (RotTLER, E. et al. 2020).

Snow can have socio-economical effects as well, as in European mountains skiing and winter tourism has a great role. Due to climate change, winter tourism faces challenges in many regions as snow period and snow depth are likely to reduce in the future. This has quite a great impact on economy and employment, while hotels, restaurants, transportation, local businesses, sport equipment sale and rental are also affected. Using artificial snow can be a solution, but it also needs specific, appropriate weather conditions (SPANDre, P. et al. 2019), moreover, the production cost and water usage increase in this case (e.g. Moreno-Gené, J. et al. 2018).

The response of snow-related variables to temperature and precipitation changes is not straightforward, it can depend on the local climatic conditions and elevation (BRown, R.D. and Моте, P.W. 2009; Brown, I. 2019). There are several studies focusing on snowrelated changes in smaller, specific domains (e.g. Klein, G. et al. 2016; Ротороvá, V. et al. 2016; MARKe, T. et al. 2018), however, as far as we know, a comprehensive analysis of different climatic regions based on the same dataset and time period is missing. Instead of separate studies for specific regions and taking into account different time periods, our aims in this paper are (i) to analyse the trends of snow-related variables in the $20^{\text {th }}$ century extended to 2010 and (ii) to investigate how snow is affected by global warming in the selected European regions. For this purpose, we use a unified methodology and a gridded database with time series that are long enough to detect long-term changes and processes. Regional anomalies can play important roles in determining local climates, therefore, subregions with different climatic characteristics are selected for this study. In order to reveal the causality of local and large-scale processes, the possible relationship between snow-related meteorological variables and the NAO index is also analysed with a special focus on the winter half-year.

\section{Data and methods}

Time series from the so-called ERA-20C dataset (Poli, P. et al. 2016) were used. ERA-20C is designed for climate applications, thus, it provides global atmospheric data for the period 1900-2010. ERA-20C is a reanalysis of ECMWF (European Centre for MediumRange Weather Forecasts) that assimilates surface pressure and marine wind observations collected in the Observation Feedback 
Archive (OFA - Herschbach, H. et al. 2015) of ERA-20C. For the assimilation, ERA-20C applies a 24-hour 4D-Var analysis (RABIER, F. et al. 2000). ERA-20C is based on the IFS (Integrated Forecast System) Cycle 38r1 (ECMWF 2013), which contains 91 atmospheric vertical levels between the surface and the $0.01 \mathrm{hPa}$ pressure level. The horizontal resolution of ERA-20C is $0.125^{\circ}$ (Poli, P. et al. 2016), which equals to about $125 \mathrm{~km}$ along a meridional. Overall, ERA-20C is considered to be a reliable database generally, which is supported by the study of WANG, Y. et al. (2017) and Wegmann, M. et al. (2017) for instance. Ideally, it would be more precise to use observational data for the analysis, however, on the one hand, meteorological stations are not evenly distributed in space; on the other hand, Wegmann, M. et al. (2017) showed that reanalysis data are able to reproduce daily and sub-decadal snow depth variability well, but a general overestimation of snow depths occurs (e.g. in Russia). The main advantage of using reanalysis data in the snow analysis is that data are available on a regular grid. In addition, reanalysis data take into account satellite data too, which provide a better spatial coverage than interpolated station data.

The monthly means of daily means of the following variables of ERA-20C were downloaded from the public website of ERA-20C (https://apps.ecmwf.int/datasets/data/era20cmoda/levtype $=$ sfc/type $=a$ an/): total precipitation, snowfall, runoff and $2 \mathrm{~m}$ temperature.

The monthly mean of the NAO index was prepared on the basis of mean sea level pres- sure of the Icelandic Low and the Azores High for the period 1900-2010 using the ERA-20C database. First, normalised sea level pressures were calculated for the two areas (the region of the Icelandic Low is defined by $60-62.25^{\circ} \mathrm{N}$; $33-38^{\circ} \mathrm{W}$, and the region of the Azores High is defined by $\left.31.75-34^{\circ} \mathrm{N} ; 24-19^{\circ} \mathrm{W}\right)$. After that, the difference between them is determined for each year on a monthly scale.

As there are quite substantial differences between climate characteristics within Europe, eight subregions (Table 1 and Figure 1) were determined for this study, so the potential local trends of the selected meteorological parameters can be assessed in the period 1900-2010. We focused on snow-related vari-

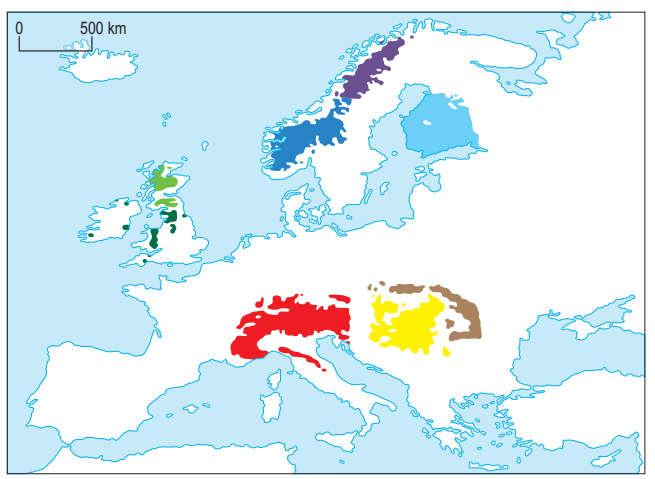

Fig. 1. Location of the selected regions: dark blue = northern Scandinavia; blue = southern Scandinavia; light blue $=$ Finland; light green $=$ northern Great Britain; dark green $=$ southern Great Britain; red = Alps; brown $=$ Carpathians; yellow $=$ Carpathian Basin .

Table 1. Regions defined for the analysis

\begin{tabular}{l|r|c|c}
\hline \multicolumn{1}{c|}{ Name } & Domain & Topography criteria, $\mathrm{m}$ & Number of grid cells \\
\hline Northern Scandinavia & $65-70^{\circ} \mathrm{N}, 10-25^{\circ} \mathrm{E}$ & \multirow{2}{*}{$>500$} & 880 \\
\hline Southern Scandinavia & $58-65^{\circ} \mathrm{N}, 5-15^{\circ} \mathrm{E}$ & & 1,331 \\
\hline Finland & $60-65^{\circ} \mathrm{N}, 20-30^{\circ} \mathrm{E}$ & \multirow{2}{*}{$<200$} & 2,077 \\
\hline Carpathian Basin & $44-50^{\circ} \mathrm{N}, 16-27^{\circ} \mathrm{E}$ & & 1,088 \\
\hline Carpathians & $44-50^{\circ} \mathrm{N}, 16-27^{\circ} \mathrm{E}$ & \multirow{2}{*}{$>500$} & 616 \\
\hline Alps & $43-49^{\circ} \mathrm{N}, 5-15^{\circ} \mathrm{E}$ & & 1,484 \\
\hline Northern Great Britain & $55-60^{\circ} \mathrm{N}, 0-10^{\circ} \mathrm{W}$ & \multirow{2}{*}{$>200$} & 242 \\
\hline Southern Great Britain & $50-55^{\circ} \mathrm{N}, 0-10^{\circ} \mathrm{W}$ & & 133 \\
\hline
\end{tabular}


ables, therefore, mainly mountainous areas (e.g. Alps, Carpathians) were selected for the detailed analysis, however, two lowlands (i.e. Carpathian Basin, Finland) were also selected in order to compare elevation-related differences. We aim to cover the differences due to the climatic conditions, i.e. northern near-polar regions with colder characteristics (Scandinavia, Finland), and regions from the oceanic climate with wet conditions and relatively low temperature fluctuations (Great Britain), and from the continental climate with higher summer temperatures and precipitation maxima generally occurring in early summer (Central Europe: Alps, Carpathians, Carpathian Basin) were selected.

The calculations are based on monthly values for different time periods, namely, years and decades. Our analysis considers the spatial averages calculated for each variable on different time scales (i.e. month, year, decade, 30-year long period) for the selected regions. In order to measure the linear dependence between two variables, the Pearson correlation method was applied, and to determine significance at 0.05 level, p-values were calculated.

\section{Results and discussion}

The present analysis starts with the joint comparison of annual cycles in general and recent changes in monthly values of hydrometeorological variables. First, the snowfall ratio (i.e. the snowfall amount relative to total precipitation) is evaluated as a function of monthly mean temperature. The scatter plot diagrams of Figure 2 summarise all the monthly values for 1900-2010, where the last 10 years are highlighted with different symbols. The overall patterns clearly show the climatic differences of the selected regions, namely, the British Isles are the warmest among these regions in winter (the average temperature of the coldest month is higher than $-5{ }^{\circ} \mathrm{C}$ ) and Scandinavia is the coldest (where the mean temperature of winter months is often below $\left.-10^{\circ} \mathrm{C}\right)$. Both in Scandinavia and in Finland
(Figure 2, a-c), the snowfall ratio in the winter months and also in March usually exceeds 0.7, sometimes it is even close to 1 , the theoretical maximum (which means that all precipitation falls as snow) and mean temperature varies between $0{ }^{\circ} \mathrm{C}$ and $-20^{\circ} \mathrm{C}$ due to the geographic locations, i.e. the vicinity of the polar Arctic. Snow occurred even in June, when the mean temperature was above $0{ }^{\circ} \mathrm{C}$, but its ratio is rather low $(<0.2)$. In the Central European regions, namely in the Alps, in the Carpathians and in the Carpathian Basin, where the mean temperature is generally higher, snowfall mostly occurs only in winter, when its monthly ratio is greater than 0.6 , but rarely reaches 1 (Figure 2, d-f). Snow also appears in November and March with a higher ratio (about 0.5), when temperature varies between $0{ }^{\circ} \mathrm{C}$ and $10{ }^{\circ} \mathrm{C}$ in these areas and in the Alps in October, too. In Great Britain, where the oceanic climate dominates with mild winters, clearly less snow is likely to occur: the snowfall ratio is usually less than 0.4 even in the winter time period of the year (Figure 2, g-h).

In northern Scandinavia (Figure 2, a), the smallest ratio of snow in January, April, November and December occurred in the last 10 years of the entire 1900-2010 period, whereas in southern Scandinavia (Figure 2, b), it occurred in April and November. In 2006, there were two minimum records of snowfall ratio (except for the summer and early autumn/late spring period): in January in northern Great Britain (0.02, Figure 2, g) and in December in Finland (0.15, Figure 2, c), which highlights the warming effects.

Analysing the monthly temperature values, the most record high values occurred after 2000, more specifically, from April to October in the Alps (Figure 2, e), in January and from May to July in the Carpathians (Figure 2, f), from April to July and in October in the Carpathian Basin (Figure 2, d). April, July and September were record warm in the British Isles (Figure 2, $\mathrm{g}-\mathrm{h}$ ), as was October in the northern regions and May in the southern parts of the domain. In the northern European regions, December was record warm after 2000 in Finland and in northern Scandinavia, where January, April 

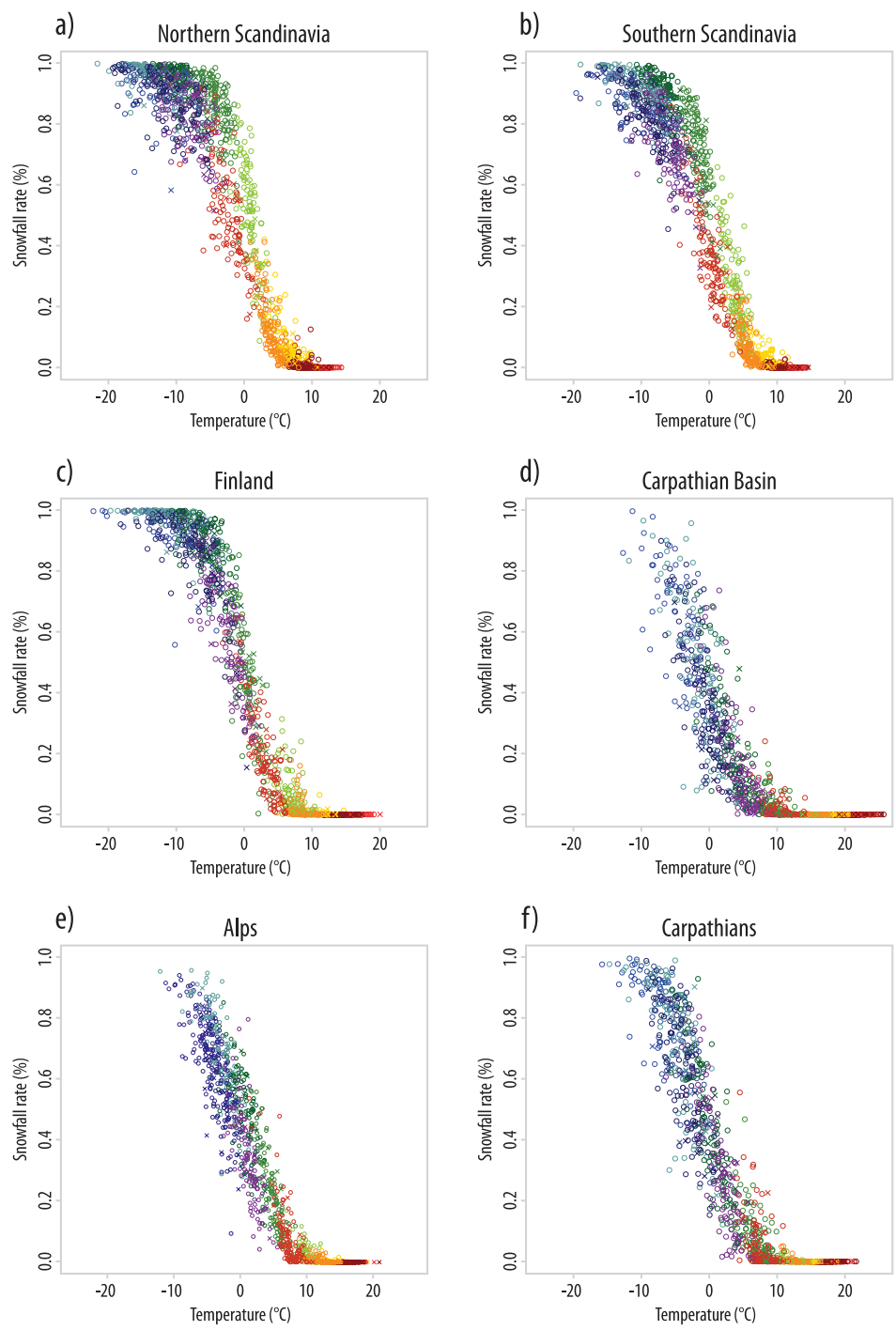

and November also showed record high values (Figure 2, a-c). In southern Scandinavia, the highest temperature values in April and in November occurred in 2002 and 2005, respectively (Figure 2, b). The first decade of the $21^{\text {st }}$ century was warmer in several regions compared to the $20^{\text {th }}$ century (WMO 2021), while in the case of snowfall ratio, the minimum record in the northern regions is associated with the start and end of the snow-period. Blahusiaková, A. et al. (2020) also found a significant increase in air temperature and a decrease in snowfall fraction and snow depth in Central Europe.

Figure 3 summarises the correlation coefficients between the snowfall ratio and mean temperature. One expects a strong reverse relationship between snow amount
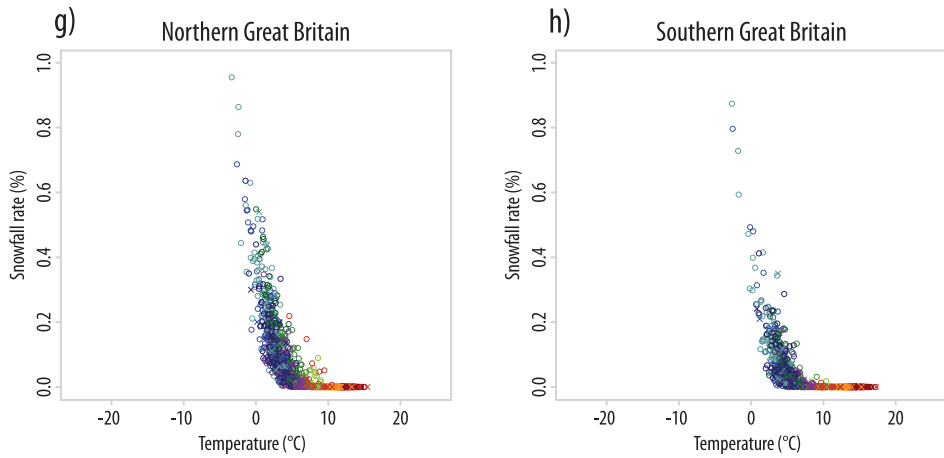

ox December ox January ox February ox March $0 \times$ April $0 \times$ May $0 \times$ June $0 \times$ July $0 \times$ August $0 \times$ September $0 \times 0$ Ctober $0 \times$ November

Fig. 2. Scatter plot diagrams of monthly temperature and snowfall ratio values in the selected regions. Each point represents a specific month from a year from the $20^{\text {th }}$ century (1900-2000) or from the $21^{\text {st }}$ century (2001-2010) indicated by ' $O$ ' and ' $x$ ', respectively. Different colours are used for the months as shown at the top. 

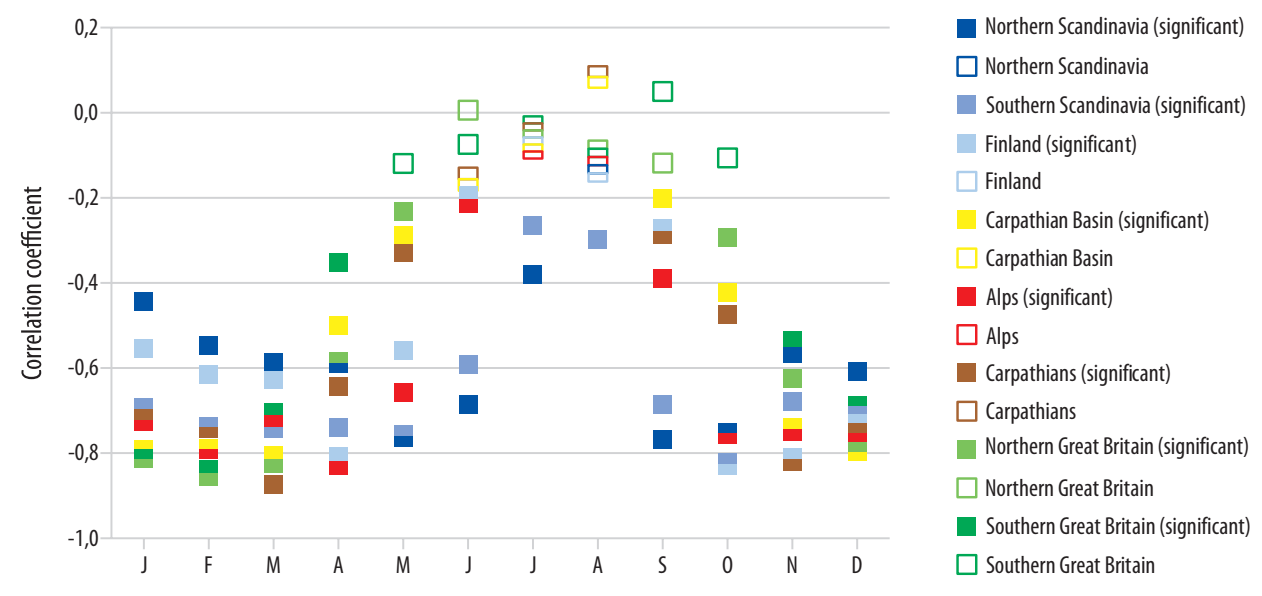

Fig. 3. Correlation coefficients between the time series of monthly snowfall ratio and mean temperature, 1901-2010. Filled and empty symbols represent significant and non-significant coefficients, respectively.

and temperature in winter: the lower the temperature, the higher the snowfall sum. KIM, Y. et al. (2013) concluded that overall snow cover in Europe expands by about 30 percent if the mean temperature decreases by $2{ }^{\circ} \mathrm{C}$.

We found that the relationship between temperature and snowfall is significant at 0.05 level from October to May in all the selected regions (except in southern Great Britain, where it is true only from November to April due to the milder climatic conditions - see; Figure 3). The strongest relationship (with a negative correlation between -0.6 and -0.9 ) occurs in March, but it varies among the regions depending on the intra-annual temperature distribution and the mean temperature values themselves. So this spring maximum occurs earlier (in February) as we get closer to the ocean, e.g. in Great Britain, and it shifts to a later time (to April or even May) in the northern regions with colder climatic conditions. The correlation coefficients are close to zero when snow rarely occurs (if at all). Similarly, Henderson, G.R. and Leathers, D.J. (2010) found that temperature and snow cover extent show a significant relationship, especially in Central and Eastern Europe, however, snow coverage generally depends on specific weather conditions in a complex way (Martin, E. and Etchevers, P. 2005). According to BeDnorz, E. (2004), the correlation between the annual number of days with a mean temperature below $0{ }^{\circ} \mathrm{C}$ during 1960-1993 and the annual number of snow cover days is about 0.46 in the European part of Russia, whereas 0.9 in the north-western parts of Poland and in the Baltic countries.

In the northern areas, the highest negative correlation occurs in autumn, but it is also stronger than -0.7 in most of the spring months (see Figure 3). In the Central European regions, the greatest correlation between temperature and the ratio of snow occurs in spring, which can be related to melting, too. The correlation exceeds -0.7 from November to March in the Alps, in the Carpathians and in the Carpathian Basin as well. In Great Britain, both in the northern and southern regions, February shows the strongest correlation, but also greater negative coefficient values occur in January and in March. To conclude: (i) in the colder, northern regions, the strongest relationship between temperature and snowfall ratio was found in autumn when the snow-season starts; (ii) in the Central European, continental areas temperature plays the most important role 
in snow-melting, therefore, the highest negative correlation between the two variables emerged in spring. Finally, (iii) in the oceanic climate, the ratio of snow is originally less (apart from some extreme years), and it occurs only in winter, so the correlation with temperature was the strongest in winter.

After the monthly analysis, the regional average snowfall sums and the mean temperatures of the time period from October to May are presented for each decade in Figure 4. In northern Scandinavia, greater average snowfall sums (360-410 $\mathrm{mm}$ ) were typical at the end of the $20^{\text {th }}$ century, while smaller amounts of snow (320-330 mm on average) appeared in the first decade of the $21^{\text {st }}$ century and in 1901-1940. Temperature also displays variation, but the 2001-2010 decade was warmer by $0.5^{\circ} \mathrm{C}$ on average than the warmest decades (1931-1940 and 1991-2000 with $-6.8^{\circ} \mathrm{C}$ ) in the $20^{\text {th }}$ century. The highest average snowfall amount (414 mm) occurred in 1981-1990 in southern Scandinavia. In the first half of the $20^{\text {th }}$ century, a warmer period emerged, hence the snowfall amount was less in this region also. Meanwhile, the warmest decade was 2001-2010 with a mean temperature of $-3.7^{\circ} \mathrm{C}$ between October and May (in the $20^{\text {th }}$ century it was never above $-4{ }^{\circ} \mathrm{C}$ on average). Finland, which is mainly lowland, shows similar tendencies to the Scandinavian regions located more towards West, but with lower snowfall amount values (maximum $\sim 220 \mathrm{~mm}$ ) due to the somewhat stronger continental effect and the less effective humidity transport of midlatitude cyclones following a northern path (VAN BebBer, W.J. 1891). Focusing on temperature, the weather is milder than in northern Scandinavia, but the warm 2001-2010 period $\left(>-2{ }^{\circ} \mathrm{C}\right)$ compared to the earlier decades can be clearly seen in this region as well.

In Central Europe, smaller amounts of snow and higher temperature values are typical because of the continental climate and the greater distance from the Arctic. In the Alps, the greatest average snowfall sums (from October to May), $236 \mathrm{~mm}$ and $237 \mathrm{~mm}$, occurred in 1961-1970 and 1971-1980, respectively, when the temperature was only $1.0^{\circ} \mathrm{C}$ and $1.2^{\circ} \mathrm{C}$ on average, the lowest during the analysed period (Figure 4, d). In the first decade of the $21^{\text {st }}$ century, temperature was record high (2.7 ${ }^{\circ} \mathrm{C}$ ) compared to the $20^{\text {th }}$ century and snowfall dropped to a lower amount (it was less than $190 \mathrm{~mm}$ ). Other studies focusing on the Alps also found a decrease in the duration of snow cover, taking into account the second half of the $20^{\text {th }}$ century (e.g. VALT, M. and Cianfarra, P. 2010; KLeIN, G. et al. 2016). This shortening occurred mainly because of the earlier snowmelt (by 5.8 days/decade on average).

In the Carpathians and in the Carpathian Basin, average snowfall (161 $\mathrm{mm}$ and 108 $\mathrm{mm}$, respectively) was more substantial in the colder period of 1961-1970 compared to the other decades (Figure 4, e-f). The warming trends of the last few decades appear clearly: the average temperature was higher by $0.6^{\circ} \mathrm{C}$ in 2001-2010 compared to the warmest decade of the $20^{\text {th }}$ century in both Central European regions. We note that studies highlighting this region showed that snow cover days have been decreased in Austria (MARKE, T. et al. 2018), Czechia (РоторovÁ, V. et al. 2016) and Romania (Birsan, M-V. and Dumitrescu, A. 2014), while only minor changes in snowrelated characteristics were detected in Poland (FALARZ, M. 2004).

Because of the oceanic climate, the least snowfall occurs in Great Britain among the analysed regions and the mean temperature is the highest in the winter half-year (Figure 4, g-h). Similarly to Scandinavia, the minimum amount of snow occurred in the first half of the $20^{\text {th }}$ century and in 2001-2010 here as well. Temperature values show a clear increase from the 1960s, but the changes are smaller compared to the Carpathian regions with strong continental influence instead of the oceanic proximity of the Great Britain regions. Brown, I. (2019) also showed that in the British Isles, the average yearly snow cover duration decreased in 1980-2010 compared to 1960-1990, especially in the northern locations.

According to KIM, Y. et al. (2013), a strong positive phase of the $\mathrm{NAO}(\mathrm{NAO}+)$ indicates warmer and wetter conditions than normal in northern Europe and below-normal tempera- 

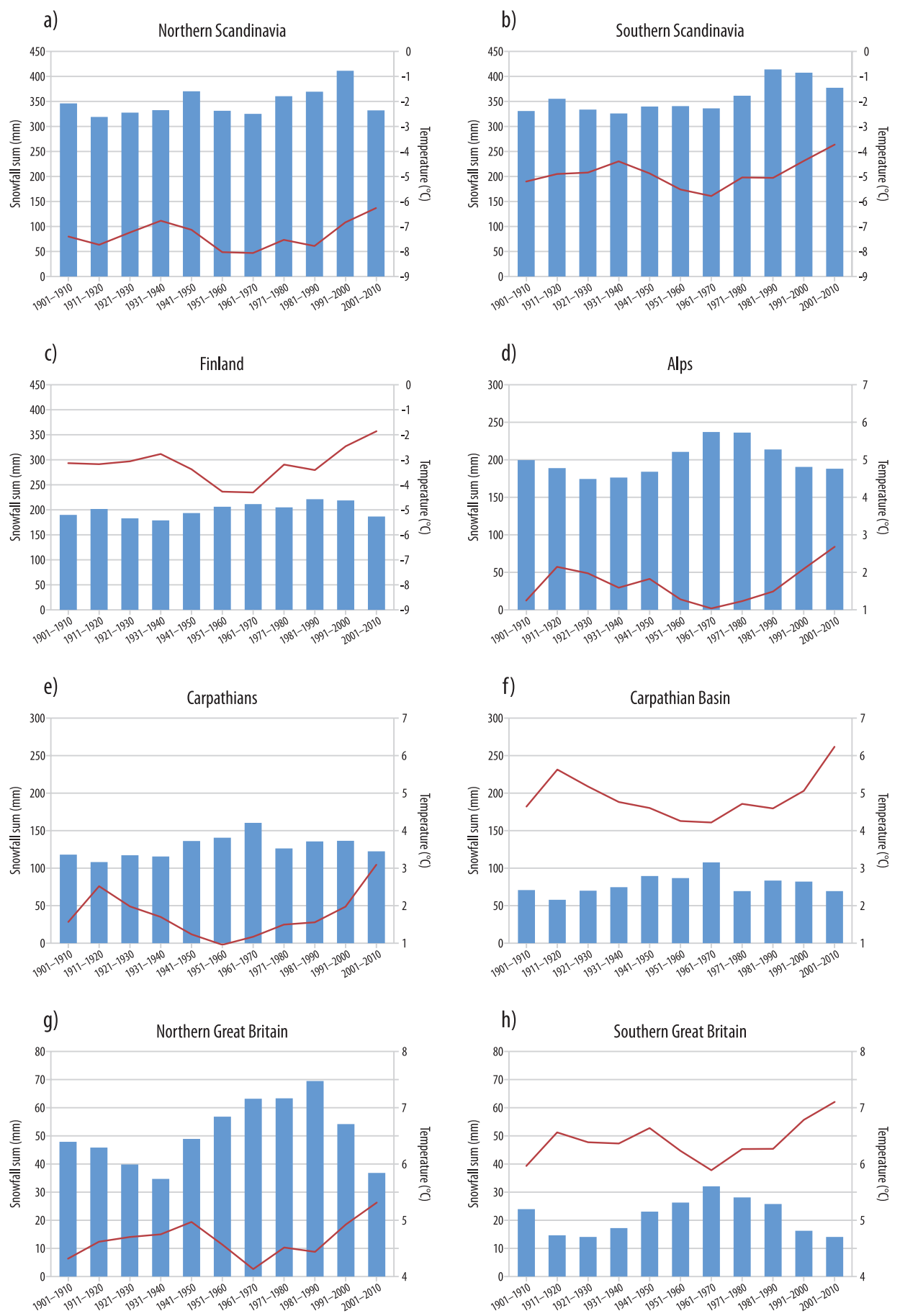

Fig. 4. Long-term changes of average temperature and average snowfall sum from October to May, for each decade in the period 1901-2010. 
ture and precipitation in the southern parts of the continent. Strong negative phases of the NAO (NAO-) usually result in opposite patterns. This is why we also investigated the relationship of temperature and snow-related variables with the NAO index for each region.

First, Figure 5 shows the regional connection between temperature and NAO. For this purpose, the NAO index and temperature values are both divided into three groups: the thresholds are defined by the $33^{\text {rd }}$ and $67^{\text {th }}$ percentiles (i.e. the lower and upper terciles) of the monthly data during the entire period 1900-2010, and then the intervals of the NAO index (NAO-1, NAO-2, NAO-3 phases) are paired with the regional temperature conditions ( $T x$ : warm conditions, Tg: around mean conditions, Tn: cold conditions), thus, resulting in nine groups. The size of the circles is determined by the number of cases that belong to the corresponding group. Since the NAO dominantly appears in winter, we selected January for this part of the analysis.

As one can see, in the case of a positive NAO index, the temperature is usually higher than its $67^{\text {th }}$ percentile (considering the period 1900-2010), especially in southern Scandinavia, in Finland and in southern Great Britain (> 20 cases; see Figure 5). When the NAO index does not indicate a specific phase, the regional temperature is roughly equally distributed among the three intervals; thus, no significant anomalies can be detected. In the case of a strong negative NAO index, lower temperature values are more frequent (> 14 cases), whereas positive temperature anomalies are rare, especially in southern Scandinavia, in Finland and in Great Britain (in southern Great Britain only three cases occurred during the 111 years).

Finally, we analysed the connection between snowfall amount (Sfx: much snow, Sfg: around average snow, $S f n$ : little snow) and the NAO index for January (Figure 6). Clearly more snowfall occurs during a strong $\mathrm{NAO}+$ phase (NAO-3) in the northern parts of Europe (especially in southern Scandinavia and Finland, where the number of cases is 22) because of more precipitation and higher temperature values (but still below $0^{\circ} \mathrm{C}$ ). When the NAO index indicates a NAO-1
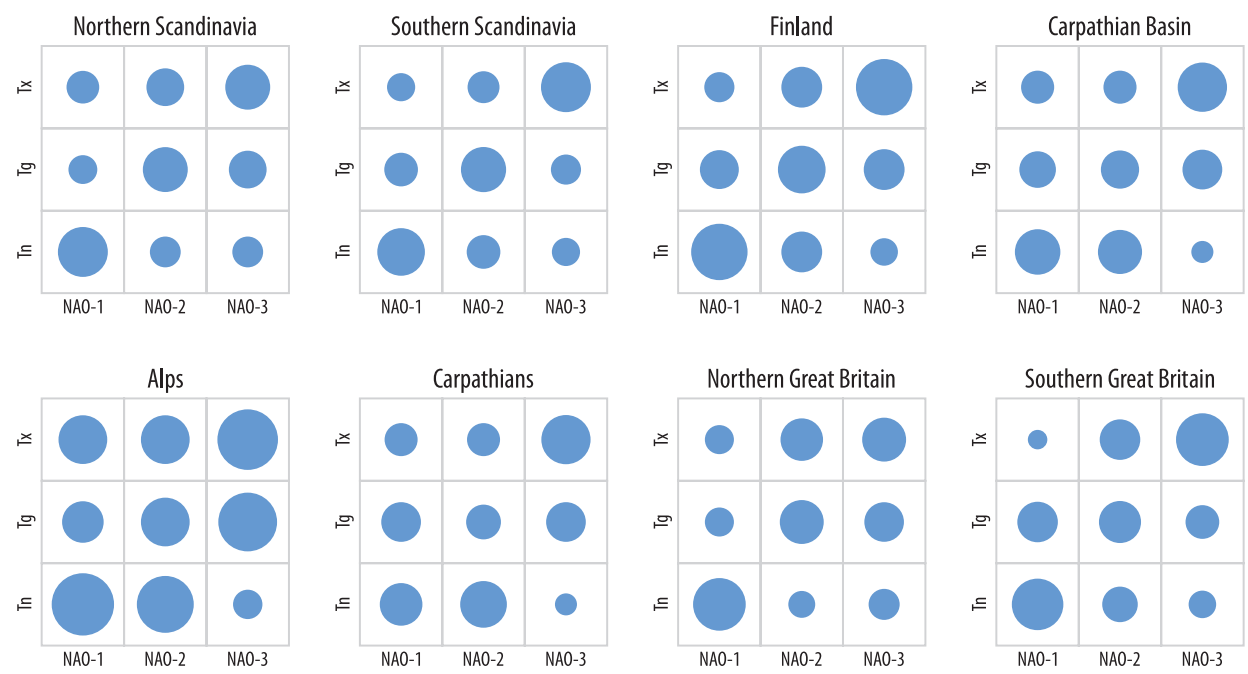

Fig. 5. Relationship between the NAO index and temperature values in January for each region. The categories were defined by the lower and upper terciles of the monthly data. The size of the circles is determined by the number of cases within the corresponding group. $\mathrm{Tx}, \mathrm{Tg}, \mathrm{Tn}=$ for explanation see the text. 

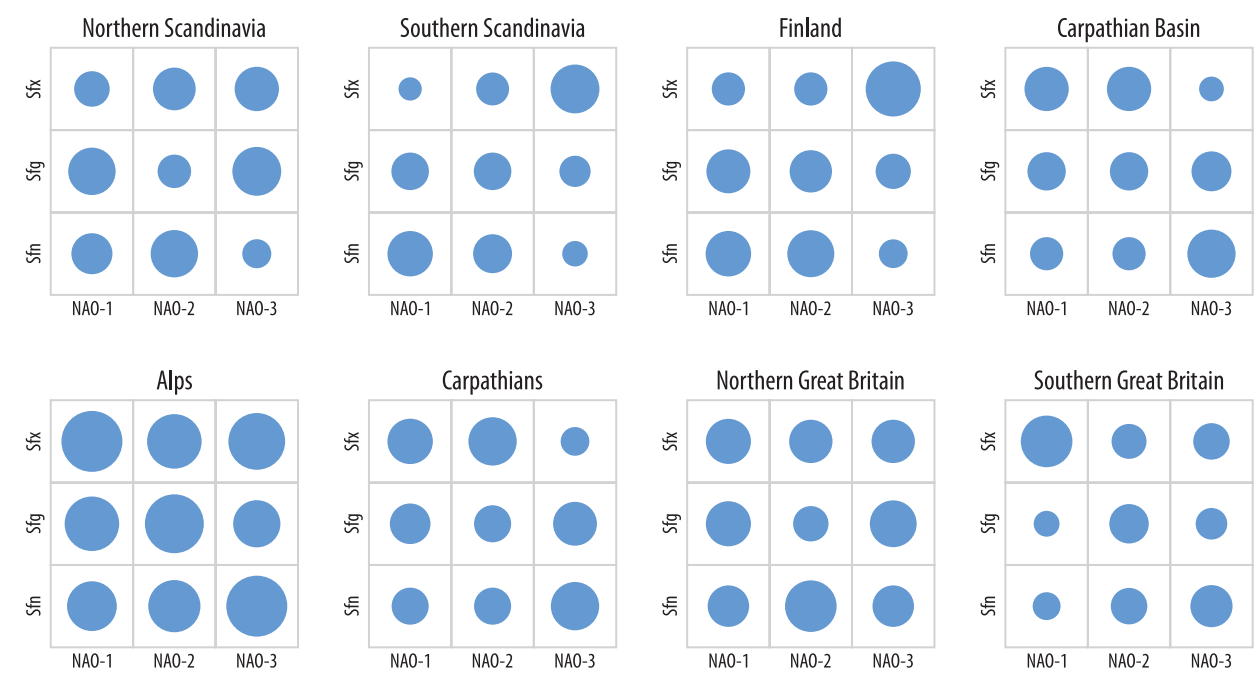

Fig. 6. Relationship between the NAO index and snowfall values in January for each region. The categories were defined by the lower and upper terciles of the monthly data. The size of the circles is determined by the number of cases within the corresponding group. Sfx, Sfg, Sfn = for explanation see the text.

case, the snowfall amount is below normal in the Scandinavian regions $(<42 \mathrm{~mm})$ and in Finland $(<32 \mathrm{~mm})$. This is explained by the differences in large-scale circulation patterns during $\mathrm{NAO}+$ and $\mathrm{NAO}-$, namely, eastern European blocking (resulting in less precipitation and lower temperature) is more likely to occur during NAO- (which is NAO-1), when the polar jet is meandering with higher amplitude and the zonal flow is less strong compared to NAO+ (which implies NAO-3) with a less meandering polar jet and strong zonal flow from the West towards Scandinavia (and northern Europe in general), resulting in more precipitation and higher temperature but still below freezing in winter in the North (Trigo, R. et al. 2002).

A NAO+ phase indicates drier climatic conditions in Central Europe, so less snowfall is likely to occur in the Carpathian Basin, in the Carpathians and in the Alps. In Romania, all the investigated snow-related parameters display a strong negative correlation with the NAO index in winter, which is due to the fact that positive temperature and negative precipitation anomalies in
Romania are associated with a high NAO index (Bojariu, R. and Paliu, D. 2001). On the contrary, when the NAO index shows a negative phase, the snowfall sum is above normal in the Carpathian Basin (> $26 \mathrm{~mm}$ ), in the Carpathians (>36 $\mathrm{mm}$ ) and in southern Great Britain $(>6 \mathrm{~mm})$, as more precipitation is related to the NAO.

BEDNORZ, E. (2004) calculated the correlation coefficients between snow cover in Eastern Europe and the NAO index and found a strong correlation in winter, which is statistically significant West of $30^{\circ}$ E. Henderson, G.R. and Leathers, D.J. (2010) also concluded that there is a strong association $(r=-0.591)$ between large snow-covered areas and the negative phase of the NAO in Europe, based on NOAA (National Oceanic and Atmospheric Administration) satellite products.

\section{Conclusions}

Snow plays an important role in many processes and conditions (e.g. surface energy flux, catchment hydrology, soil moisture, 
freshwater availability, tourism), therefore, it is important to analyse its characteristics and changes. Relationships between snow-related meteorological variables, the temperature in eight European regions and the NAO index are investigated in this study for 1900-2010. The ERA-20C dataset was used for the calculations, and in order to take into account the different climatic types, mountainous and/or plain subregions with continental (Alps, Carpathian region), oceanic (Great Britain) and polar climates (Scandinavia, Finland) were selected for the evaluation. Temperature and snow-related variables were analysed on monthly, yearly and decadal scales, too. To investigate the relationship between the selected variables and the NAO index, categories were defined by the lower and upper terciles of monthly data.

On the basis of the presented analysis the following main conclusions can be drawn.

(i) Snowfall shows a strong relationship with temperature; the ratio of snowfall can reach 1 in the colder, northern regions in winter, while it is about 0.6 in Central Europe with a continental climate, even in the coldest months.

(ii) Correlation coefficients between the snowfall ratio and mean temperature are significant from October to May in all regions. The strongest relationship occurs in March, but it varies among the regions depending on the temperature. In the vicinity of the ocean (in Great Britain), this spring maximum occurs earlier, while in the northern regions, it shifts to April or even May.

(iii) The strongest relationship between temperature and snowfall occurred in autumn in the colder, northern regions; in spring in the Central European, continental areas; and in winter in the oceanic climate.

(iv) Snowfall amount was smaller in the first decades of the $20^{\text {th }}$ and in the $21^{\text {st }}$ century as well, compared to the middle of the $20^{\text {th }}$ century, but temperature clearly shows the highest values after 2000 .

(v) The effect of the NAO appears in snow characteristics, especially in the winter months because it affects both tempera- ture values and precipitation amount. The connection is stronger in Scandinavia, in Finland, and in Great Britain than in the continental Central European regions. This can be explained by the large-scale circulation characteristics during different NAO phases with more substantial consequences for regional climatic conditions closer to the northern action centre of the NAO, i.e. the Icelandic low pressure centre.

Temperature clearly rose in the period 1900-2010, and according to climate model simulations, this trend will continue in the next decades even if the most optimistic scenario is taken into account (IPCC 2013). This will certainly affect snow-related characteristics, but the changes may not be linear. Therefore, our ultimate aim is to expand this study with further analyses for the future conditions on the basis of regional climate model outputs.

Acknowledgement: Research leading to this paper was supported by the following sources: the Hungarian National Research, Development and Innovation Fund under grants K-129162 and PD138023.

\section{REFERENCES}

Bednorz, E. 2004. Snow cover in Eastern Europe in relation to temperature, precipitation and circulation. International Journal of Climatology 24. 591-601. Available at https://doi.org/10.1002/joc.1014

Birsan, M-V. and Dumitrescu, A. 2014. Snow variability in Romania in connection to large-scale atmospheric circulation. International Journal of Climatology 34. 134-144. Available at https://doi. org/10.1002/joc.3671

Blahusiaková, A., Matousková, M., Jenicek, M., Ledvinka, O., Kliment, Z., Podolinská, J. and SNOpKová, Z. 2020. Snow and climate trends and their impact on seasonal runoff and hydrological drought types in selected mountain catchments in Central Europe. Hydrological Sciences Journal 65. (12): 2083-2096. Available at https://doi.org/10.108 0/02626667.2020.1784900

Bojariu, R. and Paliu, D. 2001. North Atlantic Oscillation projection on Romanian climate fluctuations in the cold season. In Detecting and Modelling Regional Climate Change and Associated Impacts. Eds.: Brunet, M. and Lopez, D., Berlin-Heidelberg, Springer-Verlag, 345-356. 
Brown, I. 2019. Snow cover duration and extent for Great Britain in a changing climate: Altitudinal variations and synoptic-scale influences. International Journal of Climatology 39. 4611-4626. Available at https://doi.org/10.1002/joc.6090

Brown, R.D. and Mote, P.W. 2009. The response of Northern Hemisphere snow cover to a changing Climate. Journal of Climate 22. (8): 2124-2145. Available at https://doi.org/10.1175/2008JCLI2665.1

Cohen, J. and Rind, D. 1991. The effect of snow cover on the climate. Journal of Climate 4. 689706. Available at https://doi.org/10.1175/15200442(1991)004<0689:TEOSCO>2.0.CO;2

ECMWF 2013. IFS documentation cy38r1. Available at https://www.ecmwf.int/en/forecasts/documentation-and-support/changes-ecmwf-model/ ifs-documentation

Ellis, A.W. and Leathers, D.J. 1998. The effects of a discontinuous snow cover on lower atmospheric temperature and energy flux patterns. Geophysical Research Letters 25. (12): 2161-2164. Available at https://doi.org/10.1029/98GL01582

FALARZ, M. 2004. Variability and trends in the duration and depth of snow cover in Poland in the $20^{\text {th }}$ century. International Journal of Climatology 24. 1713-1727. Available at https://doi.org/10.1002/joc.1093

Fontrodona Bach, A., van der Schrier, G., Melsen, L.A., Klein Tank, A.M.G. and Teuling, A.J. 2018. Widespread and accelerated decrease of observed mean and extreme snow depth over Europe. Geophysical Research Letters 45. (12): 312-12,319. Available at https://doi.org/10.1029/2018GL079799

Henderson, G.R. and Leathers, D.J. 2010. European snow cover extent variability and associations with atmospheric forcings. International Journal of Climatology 30. 1440-1451. Available at https://doi. org/10.1002/joc.1990

Hernández-Henríquez, M.A., Déry, S.J. and Derksen, C. 2015. Polar amplification and elevation-dependence in trends of Northern Hemisphere snow cover extent, 1971-2014. Environmental Research Letters 10. (4): 044010. Available at https://doi. org/10.1088/1748-9326/10/4/044010

Herschbach, H., Poli, P. and Dee, D. 2015. The observation feedback archive for the ICOADS and ISPD data sets. ECMWF ERA Rep. 18, 29.

IPCC 2013. Climate Change 2013: The Physical Science Basis. Contribution of Working Group I to the Fifth Assessment Report of the Intergovernmental Panel on Climate Change. Eds.: Stocker, T.F., QIn, D., Plattner, G.-K., Tignor, M., Allen, S.K., Boschung, J., Nauels, A., Xia, Y., Bex, V. and Midgley, P.M., Cambridge UK - New York USA, Cambridge University Press,

IPCC 2019. IPCC Special Report on the Ocean and Cryosphere in a Changing Climate. Eds.: Pörtner, H.-O., Roberts, D.C., Masson-Delmotte, V., Zhai,
P., Tignor, M., Poloczanska, E., Mintenbeck, K., Alegría, A., Nicolai, M., Okem, A., Petzold, J., Rama, B. and Weyer, N.M. IPCC, In press. Available at https://www.ipcc.ch/site/assets/uploads/ sites/3/2019/12/SROCC_FullReport_FINAL.pdf

KIM, Y., KIM, K-Y. and KIM, B-M. 2013. Physical mechanisms of European winter snow cover variability and its relationship to the NAO. Climate Dynamics 40. 1657-1669. Available at https://doi.org/10.1007/ s00382-012-1365-5

Klein, G., Vitasse, Y., Rixen, C., Marty, C. and Rebetez, M. 2016. Shorter snow cover duration since 1970 in the Swiss Alps due to earlier snowmelt more than to later snow onset. Climatic Change 139. 637-649. Available at https://doi.org/10.1007/ s10584-016-1806-y

Kundewicz, Z.W., Kanae, S., Seneviratne, S.I., Handmer, J., Nicholls, N., Peduzzi, P., Mechler, R., Bouwer, L.M., Arnell, N., Mach, K., MuirWood, R., Brakenridge, G.R., Kron, W., Benito, G., Honda, Y., Takahashi, K. and Sherstyukov, B. 2014. Flood risk and climate change: global and regional perspectives. Hydrological Sciences Journal 59. (1): 1-28. Available at https://doi.org/10.1080/0 2626667.2013.857411

Kunkel, K.E., Robinson, D.A., Champion, S., Yin, X., Estilow, T. and Frankson, R.M. 2016. Trends and extremes in Northern Hemisphere snow characteristics. Current Climate Change Reports 2. 65-73. Available at https://doi.org/10.1007/s40641016-0036-8

Marke, T., Hanzer, F., Olefs, M. and Strasser, U. 2018. Simulation of past changes in the Austrian snow cover 1948-2009. Journal of Hydrometeorology 19. 1529-1545. Available at https://doi.org/10.1175/ JHM-D-17-0245.1

Martin, E. and Etchevers, P. 2005. Impact of climatic changes on snow cover and snow hydrology in the French Alps. In Global Change and Mountain Regions. Advances in Global Change Research Vol 23. Eds.: Huber, U.M., Bugmann, H.K.M. and Reasoner, M.A., Dordrecht, Springer, 235-242. Available at https://doi.org/10.1007/1-4020-3508-X_24

Menne, M.J., Durre, I., Vose, R.S., Gleason, B.E. and Houston, T.G. 2012. An overview of the global historical climatology network-daily database. Journal of Atmospheric and Oceanic Technology 29. 897-910. Available at https://doi.org/10.1175/ JTECH-D-11-00103.1

Milly, P.C.D. and Dunne, K.A. 2020. Colorado river flow dwindles as warming-driven loss of reflective snow energizes evaporation. Science 367. (6483): 1252-1255. Available at https://doi.org/10.1126/ science.aay 9187

Moreno-Gené, J., Sánchez-Pulido, L., CristobalFransi, E. and Daries, N. 2018. The economic sustainability of snow tourism: The case of ski 
resorts in Austria, France, and Italy. Sustainability 10. (9): 3012. Available at https://doi.org/10.3390/ su10093012

Mudryk, L., Snatolaria-Otín, M., Krinner, G., Ménégoz, M., Derksen, C., Brutel-Vuilmet, C., Brady, M. and Essery, R. 2020. Historical Northern Hemisphere snow cover trends and projected changes in the CMIP6 multi-model ensemble. The Cryosphere 14. 2495-2514. Available at https://doi. org/10.5194/tc-14-2495-2020

OKe, T.R. 1987. Boundary Layer Climates. $2^{\text {nd }}$ edition. London, Methuen

Petersky, R. and Harpold, A. 2018. Now you see it, now you don't: a case study of ephemeral snowpacks and soil moisture response in the Great Basin, USA. Hydrology and Earth System Sciences 22. 4891-4906. Available at https://doi.org/10.5194/ hess-22-4891-2018

Poli, P., Hersbach, H., Dee, D.P., Berrisford, P., Simmons, A.J., Vitart, F., Laloyaux, P., Tan D.G.H., Peubey, C., Thépaut, J-N., Trémolet, Y., Hólm, E.V., Bonavita, M., Isaksen, L. and Fisher, M. 2016. ERA-20C: An atmospheric reanalysis of the twentieth century. Journal of Climate 29. (11): 4083-4097. Available at https://doi.org/10.1175/ JCLI-D-15-0556.1

Potopová, V., Boroneant, C., Mozny, M. and Soukup, J. 2016. Driving role of snow cover on soil moisture and drought development during the growing season in the Czech Republic. International Journal of Climatology 36. 3741-3758. Available at https:// doi.org/10.1002/joc.4588

Rabier, F., Järvinen, H., Klinker, E., Mahfouf, J.-F. and Simmons, A. 2000. The ECMWF operational implementation of four-dimensional variational assimilation. I. Experimental results with simplified physics. Quarterly Journal of the Royal Meteorological Society 126. 1143-1170. Available at https://doi. org/10.1002/qj.49712656415

Rottler, E., Francke, T., Bürger, G. and Bronstert, A. 2020. Long-term changes in central European river discharge for 1869-2016: impact of changing snow covers, reservoir constructions and an intensified hydrological cycle. Hydrology and Earth System Sciences 24. 1721-1740. Available at https:// doi.org/10.5194/hess-24-1721-2020
Spandre, P., Francois, H., Verdaillie, D., Lafaysse, M., Déqué, M., Eckert, N., George, E. and Morin, S. 2019. Climate controls on snow reliability in French Alps ski resorts. Scientific Reports 9. 8043. Available at https://doi.org/10.1038/s41598-019-44068-8

Trigo, R., Osborn, T. and Corte-Real, J. 2002. The North Atlantic Oscillation influence on Europe: Climate impacts and associated physical mechanisms. Climate Research 20. (1): 9-17.

VAlt, M. and Cianfarra, P. 2010. Recent snow cover variability in the Italian Alps. Cold Regions Science and Technology 64. (2): 146-157. Available at https:// doi.org/10.1016/j.coldregions.2010.08.008

van Bebber, W.J. 1891. Die Zugstrassen der barmetrischen Minima. Meteorologische Zeitschrift 8. 361-366.

Wang, Y., Thomas, E.R., Hou, S., Huai, B., Wu, S., Sun, W., QI, S., Ding, M. and ZHANG, Y. 2017. Snow accumulation variability over the West Antarctic ice sheet since 1900: A comparison of ice core records with ERA-20C reanalysis. Geophysical Research Letters 44. (22): 11482-11490. Available at https:// doi.org/10.1002/2017GL075135

Wegmann, M., Orsolini, Y., Dutra, E., Bulygina, O., Sterin, A. and BrönNimAnN, S. 2017. Eurasian snow depth in long-term climate reanalyses. The Cryosphere 11. 923-935. Available at https://doi. org/10.5194/tc-11-923-2017

WMO 2021. State of the Global Climate 2020. WMONo. 1264. Geneva CH, WMO. Available at https:// library.wmo.int/doc_num.php?explnum_id=10618

ZHANG, J. 2005. Warming of the arctic ice-ocean system is faster than the global average since the 1960s. Geophysical Research Letters 32. L19602. Available at https://doi.org/10.1029/2005GL024216 
